\title{
PENGARUH TEPUNG SAGU DAN KACANG MERAH TERHADAP KADAR PROTEIN DALAM PEMBUATAN NASTAR
}

\author{
Chintia Qonita Amelia ${ }^{1 *}$, Harni Sepriyani², Rosa Devitria ${ }^{2}$, Seftika Sari $^{3}$ \\ ${ }^{1 *}$ Politeknik Kesehatan Kemenkes Riau: Jalan Melur Pekanbaru \\ ${ }^{2}$ Universitas Abdurrab \\ ${ }^{3}$ Sekolah Tinggi Ilmu Farmasi Riau \\ e-mail: 1*chintia.qonita@gmail.com
}

\begin{abstract}
ABSTRAK
Potensi ketersediaan pangan lokal di Indonesia sangat melimpah antara lain serealia, palmae, umbi-umbian yang tumbuh subur di hampir seluruh wilayah Indonesia. Tepung sagu untuk pembuatan kue kering (nastar) ini kaya akan karbohidrat (pati) namun sangat rendah akan zat gizi lainnya terutama kandungan protein. Oleh karena itu, tepung sagu perlu ditambahkan dengan bahan pangan yang berprotein seperti kacang merah. Kacang merah memiliki kandungan protein cukup tinggi, kacang merah seringkali dibuat tepung dan digunakan untuk bahan tambahan dalam pembuatan kue kering. Pada penelitian dilakukan perbandingan tepung sagu dan tepung kacang merah yang digunakan adalah tepung sagu $25 \%$ : tepung kacang merah $75 \%$, tepung sagu $50 \%$ : tepung kacang merah $50 \%$, tepung sagu $75 \%$ : tepung kacang merah $25 \%$ dan tepung sagu $100 \%$. Hasil penelitian diperoleh kadar protein $4,51 \%-9,38 \%$.
\end{abstract}

Kata kunci : Sagu, kacang merah, protein

\begin{abstract}
Local food potential in Indonesia is very abundant, including cereals, palmae, tubers that thrive in almost all regions of Indonesia. Sago flour for making pastries (nastar) is rich in carbohydrates (starch) but is very low in other nutrients, especially protein content. Therefore, sago flour needs to be added with protein foods such as red beans. Red beans have a high enough protein content, red beans are made of flour and are used as additional ingredients in making pastries. In the study, a comparison of sago flour and red bean flour used was $25 \%$ sago flour: $75 \%$ red bean flour, $50 \%$ sago flour: $50 \%$ red bean flour, $75 \%$ sago flour: $25 \%$ kidney bean flour and $100 \%$ sago flour. . The results showed that the protein content was $4.51 \%-9.38 \%$.
\end{abstract}

Keywords : Sago, red bean, protein

\section{PENDAHULUAN}

Potensi ketersediaan pangan lokal di Indonesia sangat melimpah antara lain serealia, palmae, umbiumbian yang tumbuh subur dihampir seluruh wilayah Indonesia. Pada industri makanan lebih banyak menggunakan tepung terigu sebagai bahan baku utama. Sehingga secara tidak langsung memperkecil peluang produk pangan lokal yang sebetulnya mampu untuk menggantikan tepung terigu meskipun secara parsial. Salah satu contoh pangan lokal tersebut adalah sagu, namun dalam bidang industri makanan sagu masih kalah dengan terigu sebagai bahan utama pembuatan produk makanan. Selain tepung terigu memiliki kandungan gluten yang mampu membentuk struktur suatu adonan makanan, juga memiliki kandungan protein tinggi dibandingkan dengan sagu yang memiliki kandungan protein rendah namun memiliki kandugan karbohidrat lebih tinggi dari tepung terigu (Haryanto dan Pangloli, 1992).

Sagu (Metroxylon sp.) merupakan tanaman palma penghasil pati (sumber karbohidrat) dan menempati posisi keempat setelah ubi kayu, jagung dan ubi jalar. Tanaman sagu terbesar di Kawasan Timur Indonesia terutama Maluku, Papua, Sulawesi dan sebagian wilayah Barat Indonesia terutama Riau. Sagu dapat dimanfaatkan sebagai bahan baku industri pangan yang antara lain dapat diolah menjadi bahan makanan seperti bagea, mutiara sagu, kue kering, mie, biskuit, kerupuk dan laksa (Haliza dan Iriani, 2006). Menurut Badan Pusat Statistik (2015) luas area perkebunan sagu di Provinsi Riau seluas 83.691 ha dengan jumlah produksi sagu 366.031 ton.

Sumber daya pangan lokal ini dapat dijadikan sebagai bahan dasar dalam pembuatan kue salah satunya yaitu kue kering. Kue Kering adalah kue yang berbahan tepung, lemak, telur dan gula. Kue kering tergolong kedalam jenis bikuit berlemak karena menggunakan lemak setengah dari berat tepung. Biasanya kue kering banyak terdapat pada hari-hari besar seperti perayaan hari lebaran, natal dan sebagainya. Hal ini menjadi salah satu indikasi bahwa kue kering merupakan makanan kecil yang diminati masyarakat (Prasetya dkk, 2014). Nastar sebagai salah satu kue kering yang adonannya memiliki rasa manis dibuat dengan sistem kering, yaitu 
bahan-bahan diaduk sehingga menyerupai partikelpartikel seperti pasir kemudian baru dibentuk dan dioven (Agustina, 2013).

Tepung sagu untuk pembuatan kue kering (nastar) ini kaya akan karbohidrat (pati) namun sangat rendah akan zat gizi lainnya. Terutama kandungan protein dalam tepung sagu yang lebih rendah dari tepung terigu hanya $0,7 \mathrm{~g}$ dalam $100 \mathrm{~g}$ tepung sagu. Sedangkam kandungan protein dalam $100 \mathrm{~g}$ terigu sebesar $9 \mathrm{~g}$ (TKPI, 2009). Oleh karena itu, tepung sagu perlu di tambahkan dengan bahan pangan yang berprotein seperti kacang merah.

Tanaman kacang-kacangan sudah ditanam di Indonesia sejak beratus-ratus tahun yang lalu. Tanaman ini terdiri atas berbagai jenis, misalnya kacang kedelai, kacang hijau, kacang tanah, dan lain-lain. Permintaan terhadap kacang-kacangan pada masa yang akan datang, diperkirakan akan terus meningkat seiring dengan pertambahan penduduk. Menurut Badan Pusat Statistik (2015), produksi kacang merah di Indonesia tergolong cukup tinggi, yaitu mencapai 116.397 ton pada tahun 2014. Luas areal kacang merah pada tahun 2014 tercatat sekitar 22.133 hektar.

Kacang-kacangan telah lama dikenal sebagai sumber protein yang saling melengkapi dengan bijibijian, seperti beras dan gandum. Komoditi ini juga ternyata potensial sebagai sumber zat gizi lain, yaitu mineral, vitamin $\mathrm{B}$, karbohidrat kompleks dan serat makanan (Koswara, 2012). Kacang merah (Phaseolus vulgaris $L$,) memiliki kandungan protein cukup tinggi, yaitu antara 22,1 g per $100 \mathrm{~g}$ bahan dan juga kacang merah memberikan sekitar 314 kkal per $100 \mathrm{~g}$ bagian yang dapat dimakan (TKPI, 2009). Kacang merah seringkali dibuat tepung dan digunakan untuk bahan tambahan dalam pembuatan biskuit karena kandungan nilai gizinya yang tinggi terutama kandungan fosfor dan protein. Tepung kacang merah juga telah diaplikasikan secara luas, misalnya dalam pembuatan cookies atau kue kering (Pangastuti, dkk. 2013). Pengembangan produk nastar sagu dengan penambahan kacang merah diharapkan dapat meningkatkan kandungan protein produk serta dapat melakukan diversifikasi pangan dengan menggunakan tepung sagu sebagai bahan dasar pembuatan nastar.

\section{METODE PENELITIAN}

Alat-alat yang digunakan dalam penelitian ini adalah timbangan, baskom/wadah, ayakan (80 mesh), blender stainless, mixer, sendok pengaduk, loyang, oven. Bahan-bahan yang digunakan adalah tepung sagu, tepung kacang merah, tepung gula, tepung susu, telur, mentega, selai nanas. Perbandingan tepung sagu dan tepung kacang merah yang digunakan adalah tepung sagu $25 \%$ : tepung kacang merah $75 \%$ (P1), tepung sagu $50 \%$ : tepung kacang merah $50 \%(\mathrm{P} 2)$, tepung sagu $75 \%$ : tepung kacang merah $25 \%(\mathrm{P} 3)$ dan tepung sagu $100 \%$ (P4).

\subsubsection{Pembuatan tepung sagu}

Sagu basah dikeringkan dalam oven pada suhu $55^{\circ} \mathrm{C}$ selama 48 jam. Sagu diblender dan diayak dengan mengggunakan ayakan ukuran 80 mesh.

\subsubsection{Pembuatan tepung kacang merah}

Kacang merah direndam selama 48 jam, kemudian dicuci dan ditiriskan. Kacang merah dikupas dari kulitnya. Selanjutnya kacang merah dikeringkan di dalam oven pada suhu $60^{\circ} \mathrm{C}$ selama 48 jam. Kacang merah diblender dan diayak menggunakan ayakan ukuran 80 mesh.

\subsubsection{Pembuatan selai nanas}

Buah nanas dikupas, dicuci dan dipotong berbentuk dadu. Daging.buah nanas diblender, selanjutnya dimasak hingga adonan tidak putus ketika diangkat dan ditambahkan gula dan kayu manis. Adonan dimasak hingga kental selama 45 menit. Setelah masak, selai didinginkan.

\subsubsection{Pembuatan nastar}

Telur, gula halus di mixer pada kecepatan sedang selama 5 menit. Tepung sagu dan kacang merah ditambahkan sesuai perlakuan ke dalam adonan, dicampur hingga rata. Susu dan margarin ditambahkan ke dalam adonan, dan aduk kembali. Adonan dicetak dan diisi dengan selai nanas. Adonan dipanggang dalam oven pada suhu $155^{\circ} \mathrm{C}$ selama 15 menit.

\subsubsection{Penentuan kadar protein}

Penentuan kadar protein dilakukan dengan mengunakan metode Kjedhal. Sampel ditimbang 2,0 2,1 gram dan dicatat berat sampel yang tertimbang sebagai W gram. Sampel dimasukkan ke dalam tabung destruksi dan ditambahkan katalis tablet kjedahl 0,5 1,2 gram dan $10 \mathrm{~mL} \mathrm{H}_{2} \mathrm{SO}_{4}$ pekat. Campuran sampel didestruksi pada heating block di dalam lemari asam sampai terbentuk cairan sampel berwarna kehijauan dan didinginkan. Larutan $\mathrm{H}_{3} \mathrm{BO}_{3} 2 \%$ sebanyak $15 \mathrm{~mL}$ dan akuades sebanyak $10 \mathrm{~mL}$ dimasukkan kedalam erlenmeyer, dan ditambahkan 3 tetes indikator campuran metil merah dan metil biru yang akan terbentuk larutan berwarna biru. Sampel hasil destruksi diencerkan dengan akuades di dalam labu ukur $100 \mathrm{~mL}$, dihomogenkan. Larutan sampel sebanyak $25 \mathrm{~mL}$ dimasukkan ke dalam labu kjedahl dan ditambah 3 tetes indikator phenolphtalein, dialkaliskan dengan larutan $\mathrm{NaOH} 20 \%$ hingga berubah warna menjadi kemerahan(pink). Larutan penampung asam borak dan larutan campuran sampel dipasang pada alat destilasi. Didestilasi sampai larutan penampung berubah warnanya dari biru menjadi hijau dan volume bertambah menjadi sekitar $40 \mathrm{~mL}$. Hasil destilasi yang berwarna hijau dititrasi dengan larutan $\mathrm{HCl}$ hingga terbentuk warna ungu. Hasil titrasi yang diperoleh dicatat. Blanko dikerjakan dengan cara yang sama. 
Jurnal Penelitian Farmasi Indonesia 9(1), Juni 2020

ISSN : 2302-187X $\quad e$-ISSN 2656-3614

\section{HASIL DAN PEMBAHASAN}

Pada produk nastar dilakukan empat perlakuan yang pada setiap perlakuan menghasilkan dari segi rasa, aroma, tekstur dan warna yang berbeda. Produk nastar sagu dapat dilihat pada tabel 1. Kandungan protein pada nastar dapat dilihat pada tabel 2 .

Tabel 1. Deskripsi produk

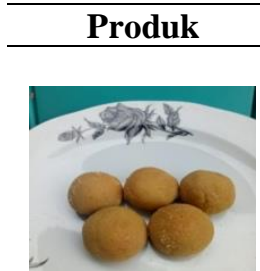

P1



P2

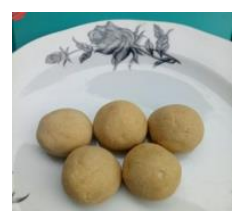

P3



P4

$\begin{array}{cccc}\text { Kuning } & \text { Manis } & \text { Khas } & \\ \text { kecoklata } & \text { dan } & \text { kue } & \text { Renyah } \\ \text { n } & \text { gurih } & \text { kering } & \end{array}$

$\begin{array}{cccc}\text { Kuning } & \text { Manis } & \text { Khas } & \\ \text { pucat } & \text { dan } & \text { kue } & \text { Renyah } \\ & \text { gurih } & \text { kering } & \end{array}$

$\begin{array}{cccc}\text { Putih } & \text { Manis } & \text { Khas } & \\ \text { pucat } & \text { dan } & \text { kue } & \text { Renyah } \\ & \text { gurih } & \text { kering } & \end{array}$
Tabel 2. Kandungan protein nastar

\begin{tabular}{lc}
\hline Produk & Kandungan Protein $(\boldsymbol{\%})$ \\
\hline P1 & 9,38 \\
\hline P2 & 8,16 \\
\hline P3 & 5,56 \\
\hline P4 & 4,51 \\
\hline
\end{tabular}

Kadar protein pada nastar sagu yang diperoleh berkisar antara 4,51\% sampai 9,38\%. Kadar protein terendah terdapat pada nastar sagu perlakuan 4 sedangkan kadar protein tertinggi terdapat pada nastar sagu perlakuan 1. Pada perlakuan 1 terdapat penambahan tepung kacang merah sebanyak $75 \%$ dengan kandungan protein sebesar 17,24 g protein per $100 \mathrm{~g}$ bahan (Yustiyani dan Setiawan, 2013), sedangkan pada perlakuan 4 yang tanpa penambahan tepung kacang merah hanya $100 \%$ tepung sagu dengan kandungan protein yang lebih sedikit daripada tepung kacang merah sebesar $0,7 \mathrm{~g}$ per $100 \mathrm{~g}$ bahan. Maka semakin banyak penambahan tepung kacang merah akan semakin meningkatkan kandungan protein pada nastar.

Menurut syarat mutu kue kering berdasarkan SNI 01-2973-1992, kadar protein minimum yang harus dipenuhi oleh nastar adalah $9 \%$, sedangkan kadar protein yang dihasilkan dari keempat perlakuan nastar sagu hanya pada perlakuan 1 yang memenuhi syarat mutu kue kering, yaitu pada tepung sagu $25 \%$ dan tepung kacang merah $75 \%$.

\section{SIMPULAN}

Berdasarkan hasil penelitian yang telah dilakukan maka dapat disimpulkan kadar protein pada nastar yakni sebesar 4,51\% - 9,38\%. Berdasarkan SNI 01-2973-1992 hanya satu perlakuan yang memenuhi syarat mutu kue kering

\section{DAFTAR PUSTAKA}

Haryanto B, Pangloli P. 1992. Potensi dan Pemanfaatan Sagu. Yogyakarta.Kanisius.

Haliza dan Iriani. 2006. Teknologi Pengolahan Untuk Penganekaragaman Konsumsi Pangan. Jurnal BB-Pascapanen Pertanian Bogor. Volume 7 (222):24.

Badan Pusat Statistik Provinsi Riau. (2015). Riau Dalam Angka 2016.

Prasetya, Meri dan Purwidiani, N. 2014. Pengaruh Proporsi Pati Garut (Maranta arundinacea L) dan Tepung Kacang Merah (Phaseolus vulgaris L) Terhadap Sifat Organoleptik Kue Semprit. E-Journal Boga. 3(3). 151-161.

Agustina, N., S. Waluyo, Warji, dan Tamrin. 2013. Pengaruh Suhu Perendaman Terhadap Koefisien Difusi dan Sifat Fisik Kacang Merah (Phaseolus Vulgaris L.). Jurnal Teknik Pertanian LampungVol. 2, No. 1: $35-42$.

Tabel Komposisi Pangan Indonesia (TKPI). 2002. Jakarta. PT Gramedia.

Koswara, S. 2012. Teknologi Pengolahan Umbiumbian, Bagian : Pengolahan Umbi Gadung. Bogor: Bogor Agricultural University.

Pangastuti, H. A., D. R. Affandi, dan D. Ishartani. 2013. Karakterisasi Sifat Fisik dan Kimia Tepung Kacang Merah (Phaseolus vulgaris L.) dengan Beberapa Perlakuan Pendahuluan. Jurnal Teknosains Pangan. 
Jurnal Penelitian Farmasi Indonesia 9(1), Juni 2020

ISSN : 2302-187X $\quad e$-ISSN 2656-3614

Yustiani dan Setiawan, B. 2013. Formulasi Bubur Instan Menggunakan Komposit Tepung Kacang Merah dan Pati Ganyong Sebagai Makanan Sapihan. Jurnal Gizi dan Pangan. 8(2):95-102

A'yun, Q dan Laily, A. N. 2015. Analisis Fitokimia Daun Pepaya (Carica Papaya L) Di Balai Penelitian Tanaman Aneka Kacang dan Umbi, Kendalpayak, Malang. Prosiding. Seminar Nasional Konservasi dan Pemanfataan Sumber Daya Alam. 134 - 137.

Latifah. 2015.Identifikasi Golongan Senyawa Flavonoid Dan Uji Aktivitas Antioksidan Pada Ekstrak Rimpng Kencur (Kaempferia galanga L) Dengan Metode Dpph (1,1 - Difenil - 2 - Pikrilhidrazil). Skripsi. Jurusan Kimia Universitas Islam Negri Maulana Malik Ibrahim Malang.

Mahatriny, N. N., Payani, N. P. S., Oka, I. B. M., dan Astuti, K. W. 2014. Skrinning Fitokimia Ekstrak Etanol Daun Pepaya (Carica papaya L) Yang Diperoleh Dari Daerah Ubud, Kabupaten Gianyar, Bali. Jurnal Farmasi Udayana. Volume 3 (1): $8-13$.

Octavia, D. R. 2009. Uji Aktivitas Penangkapan Ekstrak Petroleum Eter, Etil Asetal Dan Etanol Daun Binahong (Anreder Acordifolia (Tenote) Steen) Dengan Metode DPPH (2,2 - Dipenil - 1 Pikrilhidrazil). Skripsi. Universitas Muhammadiyah Surakarta.

Purwanto, D., Syaiful, B., Dan Ahmad, R. 2017. Uji Aktivitas Purnajiwa (Kopsia arborea blume) Dengan Berbagai Pelarut. Jurnal Kovalen. Volume 3 (1): Halaman $24-32$.

Rahayu, P. H. 2017. Perbedaan Aktivitas Antioksidan Pada Perendaman 1 Jam Dan 2 Jam Ekstrak Air
Jamur Tiram ( pleorarus astreatus). Karya Tulis Ilmiah. Program Studi DII Analis Kesehatan Insan Cendikia Medika Jombang.

Ramadhan, E Dan Sudarsono. 2013. Penangkapan Radikal 2, 2 Dipenil - 1 - Pikril Hidrazil (DPPH) Buah Pepaya (Carica pepaya L) Tua Dan Muda. Jurnal Tradisional Medicine. Volume 18 (3): Halaman 167 - 172.

Reni, E. Y. 2018. Pengantar Radikal Bebas Dan Antioksidan. CV Budi Utama: Yogyakarta.Riza, M. M. 2016. Dasar - Dasar Fitokimia. CV.Trans Info Media: Jakarta Timur.

Surya, A. 2017. Uji Aktivitas Antioksidan Pada Ubi Jalar Kuning (Ipomea batatas L) Dengan Metode DPPH (1,1 Difenil - 2- Pikrilhidrazil). Jurnal ICA (Indonesia Chemia Acta). Volume 4(1): Halaman $12-16$

Tuntun, M. 2016. Uji Efektivitas Ekstrak Daun Papaya (Carica papaya L) Terhadap Pertumbuhan Bakteri Escherichia coli dan Staphylococcus aureus. Jurnal Kesehatan. Volume 7 (3): Halaman 497 - 502.

Winarsi, H. 2007. Antioksidan Alami dan Radikal Bebas. Cetakan ke-1. Kanisius. Yogyakarta.

Yahya, M. 2016. Khasiat Daun Pepaya untuk Penderita Kanker. Dunia Sehat: Jakarta Timur.

Yuslianti, E. R. 2018. Pengantar Radikal Bebas Dan Antioksidan. Budi Utama. Yogyakarta. 